\title{
A Contiguity of Social Capital, Competence, and Business Performance Moderating by Government Policy
}

\author{
Made Gde Sudharma SANTOSA ${ }^{1}$, Wayan Gde SUPARTHA ${ }^{2}$, I. Gede RIANA ${ }^{3}$, I. B. Ketut SURYA ${ }^{4}$ \\ Received: July 03, 2020 Revised: July 28, 2020 Accepted: August 10, 2020
}

\begin{abstract}
The purpose of this study is to investigate the contiguity of social capital and competence on business performance moderating by government policy. A total sample of 225 Village Credit Institution (LPDs) managers in Bali, the hypothesis is examined using the WarpPLS analysis. The findings reveal that social capital has an important role in enhancing performance, Competence is also an important factor for managers because it can intensify performance. Social capital is largely related to the recognition of society regarding the credibility of the managers, while competence emphasizes the ability of the managers to manage the organization. Government policy must be viewed as a regulation that is able to help improve performance. However, the public policies issued by the government are still unable to help improve social capital and competence. Thus, to create public policies that are able to improve the competence and social capital, a further examination into the variables must be conducted. The findings suggest that two-way communication must be developed and synergy between the government and organizations to create opportunities and overcome the increasingly complex business challenges. The results emphasized the importance of social capital in enhancing business performance. In addition, the role of competence is of equal importance to enhance business performance.
\end{abstract}

Keywords: Government Policy, Social Capital, Competence, Business Performance

JEL Classification Code: M2, M5, M51

\section{Introduction}

Since its founding in 1984, the performance of LPDs as a whole has experienced a satisfying growth. The total assets of all LPDs reached 21.7 billions by the end of 2018 , and the total savings and deposits of the village members reached 18.2 billions in 2018. The increase in savings of

${ }^{1}$ First Author. Doctoral Program of Management, Faculty of Economics and Business, Udayana University, Indonesia.

${ }^{2}$ Departement of Management Faculty of Economics and Business, Udayana University, Indonesia.

${ }^{3}$ Corresponding Author. Departement of Management, Faculty of Economics and Business, Udayana University, Indonesia [Postal Address: Kampus Bukit, Jl. Raya Kampus Unud Jimbaran, Kec. Kuta Sel., Kabupaten Badung, Bali 80361, Indonesia] Email: gederiana@unud.ac.id ; gederiana@gmail.com

${ }^{4}$ Departement of Management Faculty of Economics and Business, Udayana University, Indonesia.

(C) Copyright: The Author(s)

This is an Open Access article distributed under the terms of the Creative Commons Attribution Non-Commercial License (https://creativecommons.org/licenses/by-nc/4.0/) which permits unrestricted non-commercial use, distribution, and reproduction in any medium, provided the original work is properly cited. the village members implies that there was an increase level of trust towards the LPD. However, the increase in government trust was not followed by the intensity of performance, spesifically in terms of the LPDs' health. Table 1 displays the health condition of LPDs in Bali in 2018 and 2019 which were obtained from Bali centre of LPDs.

Table 1: Health Condition of LPDs (2018 - 2019)

\begin{tabular}{|l|c|c|c|}
\hline Health Condition & $\mathbf{2 0 1 8}$ & $\mathbf{2 0 1 9}$ & Increase (\%) \\
\hline Healthy & 865 & 847 & -2.08 \\
\hline Quite Healthy & 242 & 230 & -4.96 \\
\hline Less Healthy & 119 & 144 & 21.01 \\
\hline Unhealthy & 58 & 55 & -5.17 \\
\hline Non-operational & 149 & 157 & 5.37 \\
\hline Total & 1433 & 1433 & \\
\hline
\end{tabular}


The problems of LPDs were allegedly due to their limited resources capacity and limited ability to analyze the external environment. This problem was further enhanced by the inadequate management skills of the human which lead to the weak performance (Riana et al., 2020). There are various problems including the behavior of managers in which are less selective in issuing credits and tend to abuse their authority. LPD is a microfinance organization that has rules, procedures, and regulations in performing their operations. Consequently, many debtors were unable to pay their obligations on time. The competence of the human resources, especially the managers, has a direct influence on organizational performance, especially HRs who are among the board of leaders. Scapolan et al. (2017) stated that high performing directors and managers are characterized by a portfolio with balanced competencies. Managers must have three main competencies, namely emotional competence (eg. achievement orientation, catalyst, and self control), social competence, and cognitive competence. A balanced portfolio of competencies allows managers to manage their organization more effectively.

Managers as the directly involved in the decision maker structure of the LPDs are expected to refer to the procedures and rules to guide their actions. This can be seen from manager's initiative to maintain productivity, adaptability, and flexibility as part of their competencies (Shet et al., 2019). Competence that is manifested in the form of credibility and good character can affect the society's trust towards the LPD. As a financial institution that is established and developed based on the custom, LPDs need to strengthen their internal management by enhancing management professionalism, while maintaining their custom based nature but balanced with the knowledge of modern organizations (Vakharia et al., 2018). Lindner (2001) stated that competence has a significant influence on performance. In fact, if measured quantitatively, the level of competence is able to improve organizational performance (Kolibacova, 2014). Therefore, it is necessary for managers to have good competence to be able to further improve the performance of their organization (Mufti et al., 2016).

Business management is nowadays increasingly emphasizing the importance of knowledge assets included competency (Astuti et al., 2020). Rohana and Abdullah (2017) revealed that there is a significant relationship between leadership performance, spedifically leadership competence on organizational performance (Ahmed et al., 2018). The leadership is a key competence in management during an economic crisis and a community crisis (Sparl, 2013), therefore managerial competence has a dominant influence on organizational performance (Zaim et al., 2013; Faisal, 2014). In addition, the role of social capital cannot be ignored in improving the organizational performance (Chowdhury et al., 2019). The practice in the social environment shows that Balinese culture, which places more emphasis on relationships between people, family lineage, and collectivism is deeply attached to the LPD. Chmelikova (2018) confirmed that the microfinance institutions rely greatly on social capital in intensify financial performance. Similarly, the local Guanxi culture (China) tends to be more collectivist and emphasizes on family relations when it is implemented in business activities. These culture can enhance the competence of the human resources and has a significant influence on performance (Park \& Luo, 2001; Anderson et al., 2010; Arribas et al., 2012).

Social capital is the concept of human capital is one of the most promising areas of development of economic science in the 21st century (Chulanova et al., 2019). Social capital, competence has become a determinant of organizational performance (Zapico \& Feinstein, 2010). Nguyen et al. (2019), mentioned that performance is on of the important concepts and measures describing the successfulness of an organization. The government policies are closely related to the existence of the LPD, even since its founding (during the pilot project) until now. The government has shown commitment to protect, encourage, and facilitate the empowerment of the LPD's capacity by issuing the Regional Law, which stated that the LPD is a village-owned financial business entity that conducts business activities within the village and for the village societies. The regional laws also emphasized that the requirement to start an LPD is that they must have a written in awig-awig (customary law). The ownership requirements show that the LPD must be protected by the custom laws. The business activities of an LPD are to compile the savings and provide credit to the village members, therefore the LPDs' main activity is to manage the finance of their village members as clients. Related to its business activities, LPDs must follow the principles of prudence to avoid bad impacts on the owners, especially to the village members who are the LPD's clients. To stimulate an accountable management, a formal regulation is needed, considering the LPDs informal management and government intervention is necessary.

The LPDs cannot be separated from the role of the government as regulators, both at the central and regional levels. Government policy is viewed as a systematic decision by the government with the purpose focused on government interest (Birkland, 2019). The government has a strategic role in establishing various policies to create a healthy competitive environment for business practitioners (Chen et al., 2016). The government has issued various policies to support business development, but often the model applied is not effective. The contradictive research on relationship between variables and the urgency of government policy is a gap to be further examined. This study aims to fill this gap by analyzing the role of government policy in moderating the influence of social capital and competence on the performance of LPDs. 


\section{Literature Review}

The social environment shows that Balinese culture emphasizes more on the relationships between people, family lineage, and collectivism. This practice is also inherent in the village's microfinance institution, namely the LPD. Chmelikova et al. (2018) found, microfinance institutions in Europe that social capital intensity is positively related to financial performance. In addition, the Chinese local culture (Guanxi) which tend to be more collectivist, also agreed that human resource competence has a significant influence on performance (Park \& Luo, 2001; Anderson et al., 2010). Scholars (Bosma et al., 2004; Sozbilir, 2018) stated that social capital has a positive effect on organizational performance, in terms of creativity and efficiency. A mature organizational process accompanied by better social capital is able to provide insights on how to improve organizational performance (Golmoradi \& Ardabili, 2016). Service organizations recommend investing in social capital because it is proven to positively influence employee commitment and performance (Ellinger et al., 2013). A number of studies showed that social capital is enhanced organizational performance (Andrews, 2010; Leana \& Pil, 2006). Liu (2017) clarified the accumulation of social capital is important for the overall performance improvement. Bosma et al. (2004) found that on newly established organizations, social capital has a positive influence on organizational performance. Moreover, Zhao et al. (2011) revealed that social capital plays an important role in enhancing the organizations ability to influence individual decisions on improving business performance. Afterwars, Syed and Kamel (2018) stated social capital is positively related to organizational performance, spesifically resourcebased social capital (Kim et al., 2013; Birasnav et al., 2019). Conversely, Subramony et al. (2018) revealed that social capital does not affect sales growth.

Startup organizations in Germany revealed thatsocial capital has a significant influence on organizational performance (Bosma et al., 2004). Organizational performance, in terms of the creativity and efficiency, is positively influenced by the social capital of managers in Turkish employment agencies (Sozbilir, 2018). Golmoradi and Ardabili, (2016) stated that organizational management accompanied by adequate social capital allows the organization to encourage and learn to improve organizational performance. In addition, social capital can be developed from effective HR practices which can stimulate organization innovation (Jiang \& Liu, 2015). Social capital is closely related to creativity and organizational performance. Thus it has a significant impact on organizational performance (Andrews, 2010; Fahmi, 2019; Harris et al., 2019). The accumulation of social capital is very important to improve performance as it can integrate human capital and organizational capital to form intellectual capital. Integration of the three capitals stimulate mutual trust within the organization, improve innovative capabilities, and enlarge the network of connections which can ultimately improve organizational development and financial performance (Liu, 2017). Scholars (Zhao et al., 2011; Sultana et al., 2019), social capital greatly contributes to the improvement of organizational capabilities and influencing individual decisions in improving business performance. Employees of various service organizations recommended to invest in social capital because it is proven to have a significant influence on employee commitment (Ellinger, 2013). Other studies (Syed \& Kamel, 2018; Kaltenbrunner \& Renzl, 2019) showed that social capital is related to organizational performance.

Felicio et al. (2014) clarified that the human capital's cognitive experiences influence their personal relationships and involvement in social capital. Organizational performance is strongly influenced by human capital through the cognitive abilities of managers. Mahajan and Benson (2013) found that organizational climate facilitates the development of social capital and in turn influences organizational performance. Social capital is a key mediating variable in the relationship between business climate and organizational performance. In contrast, Subramony et al. (2018) found that social capital has no significant influence on sales growth. The human resources who have the competence can support the business strategy which in turn will influence business performance (Brockbank et al., 2012). Competence can be improved through trainings and developments, and it should be done in order to optimize organizational performance (Lindner, 2001). Quantitatively, the higher level of competence, the higher the performance they can produce (Kolibacova, 2014). Managers who are not credible and incompetent may result in a poor image for the organization. Therefore, competencies are more able to improve organizational performance (Mufti et al, 2016). Rohana and Abdulah (2017) revealed that leaders who possess leadership skills along with various competencies significantly contribute to organizational performance. Managerial competence is a significant factor that influences organizational performance (Zaim et al., 2013). However, several studies stated that competence improves when employees have adequate social capital (Kim et al., 2012; Zhao et al., 2011).

Effendi et al. (2013) stated that government policy had no effect in improving business performance. The government policy with its various policies had not been able to strengthen business performance. The government should be more careful in setting various policies so that the policies implemented effectively fulfil their purpose (Afsharghasemi et al., 2013). The inconsistency of research results regarding the role of government policy is a gap which must be re-examined. This study examined the role of government policies by integrating it with the research model. The government has issued various regulations for the LPDs. These policies are expected to be able to help reduce the problems faced by the LPD so that they can 
perform better and grow sustainably. The government has put in a lot of effort to help businesses grow and survive in the competition (Sze et al, 2006), therefore has a strategic role in empowering businesses (Phillip et al, 2009; Chowdhury et al., 2019). Government policies must play an active role in protecting the community institutions in facing competition, developing their human resources, and providing business opportunities as much as possible through the establishment of a conducive business climate, regulatory aspects, and capital assistance. On the other hand, Korry et al. (2013) stated that the distributive and regulative government policies are able to strengthen business performance.

H1. Social capital has a positive and significant influence on the performance of LPDS

H2. Competence has a positive and significant influence on the performance of LPDs

H3. Government policy has a positive and significant influence on the performance of LPDs

H4. Government policy moderate of social capital and competence effect on the performance of LPDs

\section{Methodology}

This study adopted the quantitative paradigm by testing the hypotheses using statistical analysis. The population in this study is 1433 LPDs in Bali. The samples were selcted using the proportional random sampling technique in which the sample is taken randomly with a certain number representing the LPDs in each regency. Using Slovin's formula the total sample was determined to be 225 with the LPD managers as the unit of analysis. Data was collected by conducting interviews and distributing questionnaires to LPD managers. The questionnaire contains several statements about the research variables. The indicators of social capital was adopted from Stam, Arzlanian, and Elfring (2014), using 3 indicators, namely trust, social network, and social institutions. Competencies was adopted from the research by Shavelson (2010), which consists of 3 indicators, namely knowledge, skills, and attitude. While for the LPD's performance, using
5 indicators were adopted from the research by Kipesha, (2012), namely financial performance, social, customer perspective, learning and growth, and internal business processes. Moreover, government policy, 2 indicators used in the research by Birkland (2019) and Korry et al. (2013) were adopted, namely regulative and distributive policies. The collected data were analyzed using the WarpPLS6. The profile showed that there were more male respondents than female respondents, in which there were 117 male respondents or 63.2 percent of the total. While 139 respondents or 75.1 percent of the respondents had an education level of high school level. The majority, which was 37.5 percent of the whole respondents were at an age of 40 - 49 years old. The majority of the respondents had $9-15$ years of service, which was $35.4 \%$ of all the respondents. The distribution of respondents indicated that the managers still need guidance and trainings in business management given that the majority had an education level of high school, even though when it is in terms of experience, they have plenty.

\section{Results}

\subsection{Evaluation of the Analysis Model}

The outer model examines the model based on the validity and reliability values of the construct in the research model shown in Table 2.

A measurement can be considered reliable if the composite reliability and Cronbach alpha has a value of greater than 0.70 . The composite reliability and Cronbach alpha are the assessment of the reliability between indicator blocks in the research model. Table 2 provides information regarding the composite reliability value, in which all the constructs have a value of greater than 0.70 , thus fulfills the reliability requirement. The vifs value are all greater than $1(>1.0)$ which means that the research model is free of multicollinearity. Meanwhile, the Cronbach Alpha value of all the constructs was shown to be greater than 0.70 , thus all are deemed as reliable (Hair et al., 2010). The AVE values are all greater than $0.5(>0.50)$, therefore the model has fulfilled the convergence validity criteria.

Table 2: Composite Reliability and Cronbach's Alpha Values

\begin{tabular}{|l|c|c|c|c|}
\hline Variable & Composite reliability & Cronbach Alpha & VIFs & AVE \\
\hline Social Capital & 0.913 & 0.858 & 2.315 & 0.779 \\
\hline Competence & 0.838 & 0.707 & 2.033 & 0.635 \\
\hline Performance of LPD & 0.864 & 0.801 & 2.606 & 0.561 \\
\hline Government Policy (GP) & 0.912 & 0.808 & 1.925 & 0.839 \\
\hline GP*SocCap & 0.950 & 0.937 & 1.470 & 0.761 \\
\hline GP*Competence & 0.898 & 0.864 & 1.346 & 0.597 \\
\hline
\end{tabular}


Table 3 provides that the root of average variance extracted - AVE (diagonal) values are greater than the correlation value between variables. This shows that the discriminant validity test criteria has been fulfilled. Afterwards, the model fit and the implicit quality indices are displayed in Table 4.

The model fit of various parameters (Table 4), which were categorized as either good, accepted, or ideal. The p-values of APC, ARS, and AARS are smaller than 0.05, with the respective values being APC (0.196); ARS (0.582), and AARS (0.560). Likewise, with the values of AVIF $(1,723)$ and AFVIF $(1,949)$ being less than 3.3 , it means that there is no indication of multicollinearity between indicators and between exogenous variables. The resulting GoF value is $0.636>0.36$, which means that the model fit is very good. Furthermore, for the SPR index (1), RSCR (0.968), SSR (1), NLBCDR (0.720), there are no causal problems in the model.

\subsection{Path Analysis and Hypothesis Test}

The structural relationship between latent variables, which is conducted by assessing the path coefficient between variables and the p-values are obtained from the WarpPLS's output. All the hypothesis were examined are shown in Figure 1 as follows.

The path coefficient of each relationship in Figure 1 are then summarized and displayed in Table 5.

The test of hypothesis shows that social capital has a positive and significant influence on business performance, with a path coefficient of 0.266 and a significance ( $p$-value) of 0.002 . This value indicates that the better social capital, the higher the business performance will be. The test of hypothesis shows that the competence has a positive and significant influence on business performance with a coefficient value of 0.315 and a significance ( $p$-value) of 0.001 . These values indicate that the better the competence of managers, the higher the business performance will be.

Table 3: Discriminant Validity

\begin{tabular}{|c|l|c|c|c|c|c|c|}
\hline No & Variables & $\mathbf{1}$ & $\mathbf{2}$ & $\mathbf{3}$ & $\mathbf{4}$ & $\mathbf{5}$ & $\mathbf{6}$ \\
\hline 1 & Social Capital & $0.882^{*}$ & & & & & \\
\hline 2 & Competence & 0.570 & $0.797^{*}$ & & & \\
\hline 3 & LPD Performance & 0.644 & 0.652 & $0.749^{*}$ & & & \\
\hline 4 & Government Policy & 0.562 & 0.462 & 0.641 & $0.916^{*}$ & & \\
\hline 5 & PP*Competence $^{*}$ & 0.424 & 0.162 & 0.211 & 0.136 & $0.812^{*}$ & \\
\hline 6 & PP*SocCap & 0.193 & 0.258 & 0.090 & 0.048 & 0.412 & $0.773^{*}$ \\
\hline
\end{tabular}

${ }^{*}=($ root of average variance extracted $-\mathrm{AVE})$

Table 4: Model Fit and Quality Indices

\begin{tabular}{|c|c|c|c|c|}
\hline No & Model fit and quality indices & Fit Criteria & Result & Remark \\
\hline 1 & Average path coefficient & $P<0.05$ & $0.196, P=0.010$ & Good \\
\hline 2 & Average R-squared & $P<0.05$ & $0.582, P=<0.001$ & \\
\hline 3 & Average adjusted R-squared (AARS) & $P<0.05$ & $0.560 \mathrm{P}=<0.001$ & Good \\
\hline 4 & Average block VIF (AVIF) & acceptable if $<=5$, ideally $<=3.3$ & 1.723 & ideally \\
\hline 5 & Average full collinearity VIF (AFVIF) & acceptable if $<=5$, ideally $<=3.3$ & 1.949 & Ideally \\
\hline 6 & Sympson's paradox ratio (SPR) & acceptable if $>=0.7$, ideally $=1$ & 0,800 & acceptable \\
\hline 7 & R-squared contribution ratio (RSCR) & acceptable if $>=0.9$, ideally $=1$ & 0,968 & Ideally \\
\hline 8 & Tenenhaus GoF (GoF) & $\begin{array}{l}\text { small }>=0.1, \text { medium }>=0.25, \\
\text { large }>=0.36\end{array}$ & 0.636 & Large \\
\hline 9 & Statistical suppression ratio (SSR) & acceptable if $>=0.7$ & 1.000, & acceptable \\
\hline 10 & $\begin{array}{l}\text { Nonlinear bivariate causality direction ratio } \\
\text { (NLBCDR) }\end{array}$ & acceptable if $>=0.7$ & 0.720 & acceptable \\
\hline
\end{tabular}


Table 5: Path Analysis and Hypothesis Test

\begin{tabular}{|l|c|c|c|c|c|}
\hline \multicolumn{7}{|c|}{ Direct Influence Path Coefficient Direct and the Moderation Effect } \\
\hline Relationship between Variables & Path coefficients & P Values & effect size & SE & Remarks \\
\hline Social Capital --> Performance & 0.266 & 0.002 & 0.174 & 0.093 & Significant \\
\hline Competence --> Performance & 0.315 & $<0.001$ & 0.207 & 0.091 & Significant \\
\hline Government Pol. --> Performance & 0.327 & $<0.001$ & 0.215 & 0.091 & Significant \\
\hline GP ${ }^{*}$ SocCap--> Performance & 0.019 & 0.424 & 0.006 & 0.099 & Insignificant \\
\hline GP ${ }^{*}$ Comp --> Performance & 0.051 & 0.301 & 0.020 & 0.098 & Insignificant \\
\hline
\end{tabular}

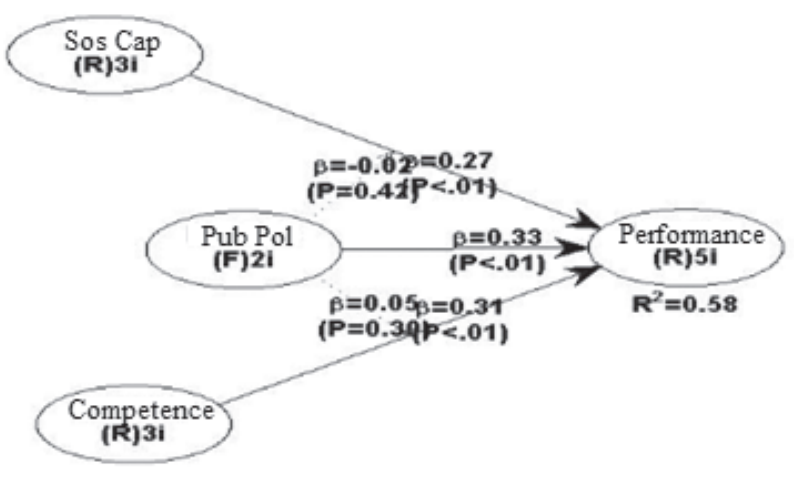

Figure 1: The structural relationship between latent variables

This result is in accordance with the second hypothesis which stated that the competence of managers has a positive influence on business performance. The test of hypothesis also shows that government policy has a positive and significant influence on business performance with a coefficient of 0.327 and a significance value (p-value) of 0.001 . These values show that government policies can improve business performance.

The moderating hypothesis shows that government policy does not strengthen the influence of social capital on business performance. This is indicated by a path coefficient value of 0.019 with a significance value of 0.424 , which is greater than 0.05 . This means that government policy is not able to strengthen the influence of social capital on business performance. The results of the hypothesis test also indicate that government policy does not significantly moderate the influence of competence on business performance. The indications path coefficient value of 0.051 with a significance of 0.351 , which is greater than 0.05 . This means that government policy is not able to strengthen the effect of competence on business performance.

\section{Discussion}

The test results show that social capital has a positive and significant influence on business performance, indicating that the social capital owned by managers are able to improve business performance. The culture in the social environment emphasizes more on relations between people, family lineage, and collectivism. This practice has also been embedded in the management of the village microfinance institution. Chmelikova et al. (2018) confirmed that a greater intensity of social capital can improve financial performance. Other researchers tried to examine the role of culture in managing businesses in China (Park \& Luo, 2001) and found that the culture in Guanxi, which tends to more collectivist and emphasizes family relations, is often embedded in business practices. The application of Guanxi culture strongly emphasizes that human resource competence is able to improve business performance (Anderson et al., 2010; Arribas et al., 2012). Social capital has also been proven to increase organizational creativity and efficiency in a number of Turkish employment agency companies (Sozbilir, 2018). Golmoradi and Ardabili, (2016) explained that social capital can help organizations improve their process and operations through learning and fostering organizational innovation, which in turn improve their performance (Jiang \& Liu, 2015). Andrews (2010) reiterated the importance of social capital in supporting sustainable performance. The research which examined the influence of social capital on performance conducted by Bosma et al, (2004) on newly established organizations in Germany showed that social capital greatly contributed to improving performance.

Social institutions and organizations are forms of social capital developed in society (Getahun \& Lehal, 2015). Social capital emphasizes the importance of social contact between groups and within the group, leading to the formation of community trust. Social capital has an important role to support the management of an organization because it 
creates a sense of camaraderie and a sense of belonging. Social capital can be in the form of networks which may be able to facilitate each other. The social capital in the form of trust between organizations and citizens motivates the organization in performing their operational activities with the society as the service users. Social capital also plays an important role in terms of problem solving and the implementation of sanctions if there are compliance issues related to transaction obligations. Saghafi and Pifeh (2019) emphasized having social capital in the society allows the organization to have certain advantages in its management process.

The findings also inform that the human resources who have the competence, knowledge, and expertise contribute to the business strategy, which in turn will improve performance. Knowledge and skills can help improve the organization's ability to build and develop their resources (Brockbank et al., 2012). Castillo and Smida (2015) stated that social capital is viewed as a competence that is determined by the convergence of three relational assets, namely orientation towards a collective goal, mutual trust, and shared values. Lindner's (2001) study examining the effect of competence on performance concluded that the influence was significant. Kolibacova (2014) explained that the level of competence is closely related to business performance. Manager's competence has a strong influence in improving performance. Employing managers who are not credible and capable may be the cause of low organizational performance, frequently resulting in the decline of the organization's image. Therefore, competent managers are needed as they have a strong influence on performance (Mufti et al., 2016).

Rohana and Abdullah (2017) revealed that the increase in organizational performance is significantly influenced by leadership skills and mastery of multiple skill sets. This is also in conformity with Ahmed et al. (2018) findings in which the improvement in leadership competence of a employee increases the performance of the organization. The leadership competence is also a key aspect in management problem and challenges such as during the economic crisis (Sparl, 2013). Lans et al. (2010) specifically stated that social competence directly affects the structural aspects of social capital. This emphasizes that social competence is an important aspect for managers in developing their entrepreneurial spirit to improve their level of success (Lans et al., 2016). Competence includes the skills, knowledge, basic attitudes, and values possessed by a person, reflected in their ability to think and act consistently. In other words, competence is not only about one's knowledge or ability, but it is also the will to do it to produce benefits.

Government policy is a program implemented to achieve specific goals are created with the purpose to achieve government welfare through the government regulations. The objective of government policies, among others is so that the community are able to enjoy government goods and government services. These benefits are needed to improve the government quality of life, both in terms of physical and non-physical aspects. Korry et al. (2013) explained that the increase in quality of distributive policies is able to improve performance. Thus, government policy strategically stimulates business development and sustainability. The government has a strategic role in creating political stability, upholding the law, improving production infrastructures, and providing educational and training assistance to protect the interest of business practitioners (Chowdhury, 2007). As the regulator, the government should ideally issue various policies to help businesses develop their competitiveness (Rahman et al., 2014).

Chen et al. (2016) conducted a study which examined the government's contribution in supporting the development of businesses. They focused on the importance of business protection provided by the Government in China, to allow the businesses to grow and develop. The role of government to allocate resources to businesses, which supports them to be more independent, is increasingly needed. The government has an important role to support businesses by optimizing infrastructures and intervening in the relationship between various companies. The government, as a stakeholder, is required to play an active role as a macro regulator in creating a fair competitive environment for business practitioners. Effendi et al. (2013) stated that government policy does not have a significant role in improving business performance. Furthermore, the various policies issued were not optimally able to fulfil its purpose in minimizing the burden of business practitioners. Moreover, Smallbone and Welter (2001) examined the support provided through the government support model. Using a sample of business owners and managers, the study empirically explored the relationship between the government support model and business growth. The findings of this study concluded that government policies are still needed by businesses to ensure sustainability. Government as the policy maker also has a role in improving organizational performance (Zapico \& Feinstein, 2010). Zhao et al. (2011) clarify social capital contributes the organizations ability to increase the active role of individuals to improve performance. Other studies also suggested to invest in social capital because it has been proven to have an impact on the employees commitment and performance (Ellinger, 2013; Syed \& Kamel, 2018).

The establishment of LPD was initially supported by the government with an injection of funds which were provided to each customary village. In addition to funding assistance, government also developed regulations that govern institutional operations while positioning itself as 
the overseer. The results showed that government policies are able to help improve business performance (Korry et al., 2013), but are not able to help increase the social capital of managers to improve performance. Government policy is deemed as beneficial as long as the regulations do not conflict with the organization's norms. Other findings indicated that competence can support the work system, and thus has an influence on performance (Rohana \& Abdullah, 2017). Competence is needed to improve operational effectiveness. The competence of managers is one of the most important aspects to improve performance. Organizations manage their human resources emphasizing on competence as the basis to conduct, recruitment, assessment, training and development, in order to meet the effective performance standards (Zhu et al., 2019). The competence of individuals enables them to understand the how, when and why certain information are useful for the organization. Thus, competence is greatly needed so that organizations can grow continuously. However, government policies have not been able to improve the competence in improving performance. The right regulation is needed to direct management towards a new paradigm. The number of LPDs that are not healthy tend to increase, thus government interventions in the form of regulative and distributive assistance are needed. The assistance should be focused on improving the competence of managers. Competence is reflected in the ability and capacity of individuals to perform various tasks in their job (Caldas et al., 2018). Competence is fundamentally composed of two abilities, namely intellectual ability and physical ability (Robbins \& Judge, 2015).

\section{Conclusion}

This research provides a deeper understanding about social capital and competencies and their effects on business performance. This study also provides an overview of the role of government in improving business performance. This research is also one of the studies that discuss about the social capital theory in organizations managed with a cultural basis, namely the Village Credit Institutions (LPDs) that only exist in Bali, Indonesia. The results emphasized the importance of social capital in enhancing business performance. In addition, the role of competence is of equal importance to enhance business performance. Although it is managed conventionally, organizations that are managed with a cultural basis must still pay attention to the competence of their HRs in their operation because be able to achieve their vision and missions. This research also clarifies that government can support businesses by providing a more conducive business climate so that organizations can compete fairly. However, government policies should be focused on the organizations' needs to develop their independency in facing challenges and opportunities. Government policies have not been able to strengthen the influence of social capital and competence on business performance. The government must be able to identify the factors that make organizations feel more comfortable in the competition. As the regulator, the government policies should be focused on honing the ability of organizations to compete more competitively. Afterwards, synergy is needed to detect the needs of the organization and detect future challenges that are relatively unpredictable.

\section{References}

Afsharghasemi, A., Zain, M., Sambasivan, M., \& Imm, S. N. S. (2013). Market orientation, government regulation, competitive advantage and internationalization of SMEs: A study in Malaysia. Journal of Business Administration Research, 2(2), 13-22.

Ahmed, A., Khuwaja, F. M., Brohi, N. A., Othman, I., \& Bin, L. (2018). Organizational factors and organizational performance: A resource-based view and social exchange theory viewpoint. International Journal of Academic Research in Business and Social Sciences, 8(3), 579-599.

Anderson, H. J., Baur, J. E., Griffith, J. A., \& Buckley, M. R. (2017). What works for you may not work for (Gen) Me: Limitations of present leadership theories for the new generation. The Leadership Quarterly, 28(1), 245-260.

Andrews, R. (2010). Organizational sosial capital, structure and performance. Human Relations, 63(5), 583-608.

Arribas, I., Hernandez, P, \& Vila J. E., (2012). Guanxi, performance and innovation in entrepreneurial service projects. Discussion Paper in Economic Behaviour, 51(1), 173-183.

Astuti, R. N., Fachrurrozie, F., Amal, M. I., \& Zahra, S. F. (2020). Does Audit Committee Quality Mediate Determinants of Intellectual Capital Disclosure?. Journal of Asian Finance, Economics and Business, 7(7), 199-208. https://doi. org/10.13106/jafeb.2020.vol7.no7.199

Birasnav, M., Chaudhary, R., \& Scillitoe, J. (2019). Integration of sosial capital and organizational learning theories to improve operational performance. Global Journal of Flexible Systems Management, 20(2), 141-155.

Birkland, T. A. (2019). An introduction to the policy process: Theories, concepts, and models of public policy making. New York, NY: Routledge.

Bosma, N., van Praag, M., Thurik, R., \& de Wit, G. (2004). The value of human and sosial capital investments for the business performance of startups. Small Business Economics, 23(3), 227-236.

Brockbank, W., Ulrich, D., Younge, J., \& Ulrich, M. (2012). The Future is Now: HR Competencies for High Performance. The RBL White Paper Series. Provo, UT: The RBL Group. Available at: https://rbl-net.s3.amazonaws.com/hrcs/2012/ FutureisNow-HRCompsforHighPerf.pdf 
Caldas, M., Carvalho Bullara, R. F., Wood, T., \& Silva Samartini, A. L. (2018). Testing the Influence of Individual-Level Competency Proficiency on Unit-Level Performance. In: Academy of Management Proceedings (Vol. 2018, No. 1, p. 18382). Briarcliff Manor, NY: Academy of Management

Castillo, R. E. R., \& Smida, A. (2015). The formation of organizational social capital into technology-based micro enterprises. Contaduría y Administración, 60(S1), 57-81.

Chen, S.-T., Haga, K. Y. A., \& Fong, C. M. (2016). The effects of institutional legitimacy, social capital, and government relationship on clustered firms' performance in emerging economies. Journal of Organizational Change Management, 29(4), 529-550.

Chmelikova, G., Krauss, A., \& Dvouletý, O. (2019). Performance of microfinance institutions in Europe-Does social capital matter?. Socio-Economic Planning Sciences, 68, Article ID 100670. https://doi.org/10.1016/j.seps.2018.11.007

Chowdhury, M., Prayag, G., Orchiston, C., \& Spector, S. (2019). Postdisaster sosial capital, adaptive resilience and business performance of tourism organizations in Christchurch, New Zealand. Journal of Travel Research, 58(7), 1209-1226.

Chulanova, Z. K., Satybaldin, A. A., \& Koshanov, A. K. (2019). Methodology for assessing the state of human capital in the context of innovative development of the economy: A threelevel approach. Journal of Asian Finance, Economics and Business, 6(1), 321-328. http://doi.org/10.13106/jafeb.2019. vol6.no1.321

Effendi, S., Hadiwidjojo, D., Solimun., \& Noermijati. (2013). The Effect of Entrepreneurship Orientation on the Small Business Performance with Government Role as the Moderator Variable and Managerial Competence as the Mediating Variable on the Small Business of Apparel Industry in Cipulir Market, South Jakarta. IOSR Journal of Business and Management, 8(1), 49-55.

Ellinger, A. E., Musgrove, C. C. F., Ellinger, A. D., Bachrach, D. G., Elmadağ Baş, A. B., \& Wang, Y. L. (2013). Influences of organizational investments in sosial capital on service employee commitment and performance. Journal of Business Research, 66(8), 1124-1133.

Fahmi, F. Z. (2019). Business networks, social capital and the economic performance of creative and cultural industries: The case of Indonesia. Asia Pacific Viewpoint, 60(3), 370-385.

Faisal, M. (2014). Effect of Competence, Leadership and Organizational Culture toward Organization Commitment and Performance of Civil Servants on the Regional Office of Ministry of Religious Affairs in the Province of the West Sulawesi. Internal Communications \& Organizational Behavior eJournal, 7(14), 1-16.

Felicio, J. A., Couto, E., \& Caiado, J. (2014). Human capital, sosial capital and organizational performance. Management Decision, $52(2), 350-364$.

Getahun, D. A., \& Lehal, R. (2015). Organizational citizenship behavior in relation to social capital capital in North West
Region of Ehpthiopian electric power corperation: A case of Ambara Regional state. Intertional Journal of Applied Research, 1(2), 1044-1051.

Golmoradi, R., \& Ardabili, F. S. (2016). The Effects of Sosial Capital and Leadership Styles on Organizational Learning. Procedia Sosial and Behavioral Sciences, 230(May), 372-378.

Hair, J. F., Black, W. C., Babin, B. J., \& Anderson, R. E. (2010). Multivariate Data Analysis (7th ed.). Upper Saddle River, NJ: Pearson Prentice Hall.

Harris, C. M., Wright, P. M., \& McMahan, G. C. (2019). The emergence of human capital: Roles of sosial capital and coordination that drive unit performance. Human Resource Management Journal, 29(2), 162-180.

Jiang, J. Y., \& Liu, C. W. (2015). High performance work systems and organizational effectiveness: The mediating role of sosial capital. Human Resource Management Review, 25(1), 126-137.

Kaltenbrunner, K., \& Renzl, B. (2019). Sosial Capital in Emerging Collaboration between NPOs and Volunteers: Performance Effects and Sustainability Prospects in Disaster Relief. Voluntas: International Journal of Voluntary and Nonprofit Organizations, 30(5), 976-990.

Kim, T. T., Lee, G., Paek, S., \& Lee, S. (2013). Sosial capital, knowledge sharing and organizational performance: What structural relationship do they have in hotels? International Journal of Contemporary Hospitality Management, 25(5), 683-704.

Kipesha, E. F. (2012). Efficiency of Microfinance Institutions in East Africa: a data envelopment analysis. European Journal of Business and Management, 4(17), 77- 88.

Kolibacova, G. (2014). The relationship between competency and performance. Acta Universitatis Agriculturae et Silviculturae Mendelianae Brunensis, 62(6), 1315-1327.

Korry, I. N. S., Troena, E. A., Hadiwidjojo, D., \& Noermijati. (2013). The Role of Entrepreneurial Orientation in Mediating the Effect of Organizational Culture and Government Policy toward Business Performance (Case Study: Koperasi Unit Desa in Bali Province). International Journal of Business and Commerce, 2(12), 29-42. [Indonesian]

Lans, T., Gulikers, J., \& Batterink, M. (2010). Moving beyond traditional measures of entrepreneurial intentions in a study among life-sciences students in the Netherlands. Research in Post-Compulsory Education, 15(3), 259-274.

Leana, C. R., \& Pil, F. K. (2006). Sosial capital and organizational performance: Evidence from urban government schools. Organization Science, 17, 353-366.

Lindner, J. R. (2001). Competency Assessment and Human Resource Management Performance of County Extension Chairs in Ohio. Journal of Agricultural Education, 42(4), 21-31.

Liu, C. H. (2017). The relationships among intellectual capital, sosial capital, and performance - The moderating role of business ties and environmental uncertainty. Tourism Management, 61, $553-561$. 
Mahajan, A., \& Benson, P. (2013). Organisational justice climate, sosial capital and firm performance. Journal of Management Development, 32(7), 721-736.

Mufti, O., Parvaiz, G. S., Wahab, M., \& Durrani, M. (2016). Human resource competencies and organizational performance: A study on banking sektor managers in Pakistan. Journal of Managerial Sciences, 10(1), 83-104.

Nguyen, P. A., Nguyen, A. H., Ngo, T. P., \& Nguyen, P. V. (2019). The relationship between productivity and firm's performance: evidence from listed firms in Vietnam stock exchange. Journal of Asian Finance, Economics and Business, 6(3), 131-140. https://doi.org/10.13106/jafeb.2019.vol6.no3.131

Park, S., \& Luo, Y. (2001). Guanxi and Organizational Dynamics: Organizational Networking in Chinese Firms. Strategic Management Journal, 22, 455-477.

Phillip, H. P., Wright, M., Ucbasaran, D., \& Tan, W.L. (2009). Corporate entrepreneurship: current research and future directions. Journal of Business Venturing, 24, 197-205.

Rahman, A, H., Jarrar, M. T., \& Omira, O. D. (2014). Leadership styles and performance of public sector organizations: the case of Saudi Arabia. Journal of Business Management and Accounting, 4, 55-62.

Riana, I. G., Suparna, G., Suwandana, I. G. M., Kot, S., \& Rajiani, I. (2020). Human resource management in promoting innovation and organizational performance. Problems and Perspectives in Management, 18(1), 107-118.

Robbins, S. P., \& Judge, T. A. (2015). Organizational Behaviour. London, UK: Pearson.

Rohana, N. S. M., \& Abdullah, C. Z. (2017). Leadership Competencies and Organizational Performance: Review and Proposed Framework. International Journal of Academic Research in Business and Social Sciences, 7(8), 824-831.

Saghafi, M., \& Pifeh, A. (2019). Social Capital and the Competency of Accountants in General section. Accounting and Financial Management Letters, 1(1). [Indonesian]

Scapolan, A., Montanari, F., Bonesso, S., Gerli, F., \& Mizzau, L. (2017). Behavioural competencies and organizational performance in Italian performing arts: An exploratory study. Academia Revista Latinoamericana de Administración, 30(2), 192-214.

Shavelson, R. J. (2010). On the measurement of competency. Empirical Research in Vocational Education and Training, 2(1), 41-63.

Shet, S. V., Patil, S. V., \& Chandawarkar, M. R. (2019). Competency based superior performance and organizational effectiveness. International Journal of Productivity and Performance Management, 68(4), 753-773.
Smallbone, D., \& Welter, F. (2001). The role of government in SME development in transition economies. International Small Business Journal, 19(4), 63-77.

Sozbilir, F. (2018). The interaction between sosial capital, creativity and efficiency in organizations. Thinking Skills and Creativity, 27, 92-100

Sparl, P., Žnidaršič, A., Kasper, H., Mühlbacher, J., \& Kovač, J. (2013). Management Competencies and Organizational Performance in CEE: A Comparison of Slovenia and Austria, Organizacija, 46(5), 214-220.

Stam, W., Arzlanian, S., \& Elfring, T. (2014). Social capital of entrepreneurs and small firm performance: A meta-analysis of contextual and methodological moderators. Journal of Business Venturing, 29(1), 152-173.

Subramony, M., Segers, J., Chadwick, C., \& Shyamsunder, A. (2018). Leadership development practice bundles and organizational performance: The mediating role of human capital and sosial capital. Journal of Business Research, 83, 120-129.

Sultana, R., Im, I., \& Im, K. S. (2019). Do IT freelancers increase their entrepreneurial behavior and performance by using IT self-efficacy and sosial capital? Evidence from Bangladesh. Information \& Management, 56(6), 103-133.

Syed, A. A. T., \& Kamel, F. (2018). Exploring the relationships of strategic entrepreneurship and sosial capital to sustainable supply chain management and organizational performance. International Journal of Productivity and Performance Management, 67(9), 2046-2070.

Vakharia, N., Vecco, M., Srakar, A., \& Janardhan, D. (2018). Knowledge centricity and organizational performance: an empirical study of the performing arts. Journal of Knowledge Management, 22(5), 1124-1152.

Zaim, H., Muhammed, S., \& Tarim, M. (2019). Relationship between knowledge management processes and performance: Critical role of knowledge utilization in organizations. Knowledge Management Research \& Practice, 17(1), 24-38.

Zapico-Goni, E., \& Feinstein, O. (2010). Evaluation of government performance and publik policies in Spain. ECD Policy Research Working Paper Series No. 22. Washington, DC: World Bank, Evaluation Capacity Development (ECD). http://hdl.handle. net/10986/27913

Zhao, W., Ritchie, J. R. B., \& Echtner, C. M. (2011). Sosial capital and tourism entrepreneurship, Annals of Tourism Research, 38(4), 1570-1593. https://doi.org/10.1016/j.annals.2011.02.006

Zhu, Y., Yang, H., \& Bai, G. (2019). Relationship between Staff Competency and Performance of Service-Oriented Manufacturing Enterprises in China. Transformations in Business \& Economics, 18(1), 234-248. 